

\title{
Fate of the lower lithosphere during shallow-angle subduction: The Laramide example
}

\begin{abstract}
Alan D. Chapman, Ojashvi Rautela, Geology Dept., Macalester College, St. Paul, Minnesota 55105, USA; Jessie Shields, Department of Earth and Environmental Sciences, California State University, Fresno, California 93740, USA; Mihai N. Ducea, Dept. of Geosciences, University of Arizona, Tucson, Arizona 85721, USA, and Faculty of Geology and Geophysics, University of Bucharest, 010041, Bucharest, Romania; and Jason Saleeby, Division of Geological and Planetary Sciences, California Institute of Technology, Pasadena, California 91125, USA
\end{abstract}

\section{ABSTRACT}

Continental arc lower crust and underlying mantle wedge assemblages native to the Mojave Desert were dislodged, transported eastward during Laramide shallow-angle subduction, and attached to the base of the Colorado Plateau transition zone (central Arizona, USA) and further inboard. We identify here two late Oligocene xenolith localities from the transition zone (Camp Creek and Chino Valley) that likely contain remnants of the missing Mojave lithosphere. Geochemical, isotopic, and thermobarometric data from garnet clinopyroxenite, the dominant xenolith type at both studied localities, strongly suggest a continental arc residue ("arclogite") rather than a lower plate subduction ("eclogite") origin. Zircon grains extracted from these nodules yield a bimodal age distribution with peaks at ca. 75 and $150 \mathrm{Ma}$, overlapping ages of continental arc magmas emplaced into the Mojave Desert (the southern California batholith) and suggesting a consanguineous relationship. In contrast, Mesozoic and early Cenozoic igneous rocks from SW Arizona, with age peaks at ca. 60 and $170 \mathrm{Ma}$, do not provide as close a match. In light of these results, we suggest that a mafic keel to the southern California batholith: (1) formed in two discrete (Late Jurassic and Late Cretaceous) pulses; (2) was transported along the Moho $\sim 500 \mathrm{~km}$ eastward along the leading edge of the shallowly subducting Farallon plate; and (3) was affixed to the base of the crust in central Arizona. Titanite U-Pb and garnet Sm-Nd ages spanning ca. 60-30 Ma suggest that displaced arclogite remained at $>600{ }^{\circ} \mathrm{C}$ for tens of millions of years following its dispersal and until entrainment in host latite. The lack of arclogite and
\end{abstract}

abundance of spinel peridotite xenoliths in ca. $15 \mathrm{Ma}$ and younger volcanic host rocks and the presence of a vertical high-seismicvelocity anomaly beneath the western Colorado Plateau suggest that arclogite has been foundering into the mantle and being replaced by upwelling asthenosphere since the early Miocene.

\section{INTRODUCTION AND BACKGROUND}

\section{The SW North American Cordillera}

The Laramide orogeny was a regional compressional event that evolved from Late Cretaceous-early Paleogene contraction of the SW margin of North America to Eocene-early Oligocene deformation up to $2,000 \mathrm{~km}$ inboard in the craton interior (Saleeby, 2003; DeCelles, 2004; Copeland et al., 2017). A commonly cited mechanism for the orogeny is intensified traction and tectonic erosion of the lowermost crust and upper subcontinental mantle lithosphere (LC-SCML) due to flattening of an $\sim 500-\mathrm{km}$-wide segment of the subducting Farallon plate (Livaccari et al., 1981; Bird, 1988; Saleeby, 2003; Axen et al., 2018). Parts of the central Andean orogen are regarded as the best modern analogue, where shallow slab segments coincide with colliding aseismic ridges and oceanic plateaux (e.g., Gutscher et al., 2000). Analysis of plate reconstructions for the Pacific-Farallon ridge led to the interpretation that the Laramide orogeny resulted from the subduction of conjugate massifs to the Hess and Shatsky oceanic plateaux (Livaccari et al., 1981; Liu et al., 2010). Furthermore, an 500-km-wide Laramide deformation corridor parallels the subduction trajectory of inferred Hess and Shatsky conjugates, which were embedded in the Farallon plate as they subducted in Laramide time (Saleeby, 2003; Liu et al., 2010). The damage zone consists of the southern California batholith (SCB) of the Mojave Desert and the southernmost Sierra Nevada batholith (SNB; Fig. 1, inset).

As emphasized below, the impact of oceanic plateaux is consistent with evidence for the shutdown of arc magmatism, deep crustal exhumation, tectonic underplating of trench sediments, and-the focus of this research-removal of the LC-SCML (e.g., Saleeby, 2003; Luffi et al., 2009; Chapman et al., 2012; Chapman, 2017; Ducea and Chapman, 2018).

\section{Overview of the SCB Domain of the Laramide Corridor}

The formerly contiguous SNB-SCBPeninsular Ranges batholithic belt was a $>2000-\mathrm{km}$-long NNW-trending granitic arc emplaced largely during three magmatic "flare-up" events at ca. 230-210 Ma, ca. 160-150 Ma, and ca. 100-75 Ma (e.g., Ducea, 2001). In contrast to the SNB to the north and the Peninsular Ranges batholith to the south (Fig. 1), much of the $\sim 500-\mathrm{km}$ long SCB is rootless, lying tectonically above underplated trench assemblages (the Rand and related schists) that were transported inboard by shallow-angle subduction (Jacobson et al., 1988; Grove et al., 2003; Chapman, 2017; Ducea and Chapman, 2018). These schists are exposed in the footwall of the shallowly dipping Rand fault, interpreted as a remobilized subduction megathrust (e.g., Cheadle et al., 1986; Chapman, 2017), beneath deep crustal level SCB assemblages and the southern SNB (Fig. 1). 


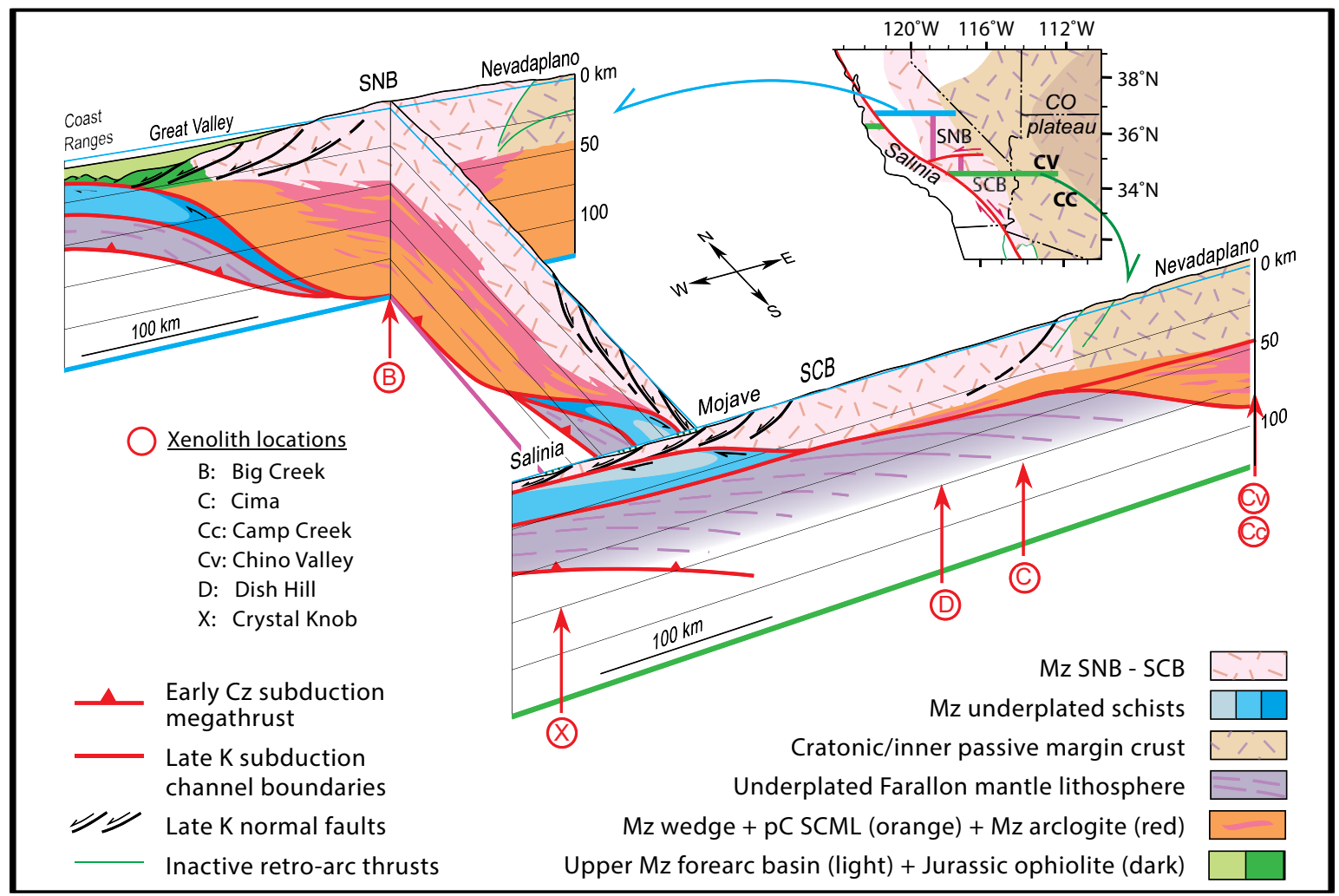

Figure 1. Fence diagram showing idealized lithospheric structure for beginning of Cenozoic time for sections across Sierra Nevada batholith (SNB)-Great Valley forearc, southern California batholith (SCB)-Colorado Plateau transition zone, and linking section across the southern SNB. Locations of sections shown on inset. Cz-Cenozoic; CO-Colorado; K-Cretaceous; MzMesozoic; pC-Precambrian; SCML-subcontinental mantle lithosphere.

The SNB is tilted into a southward deepening section spanning paleodepths of $\sim 10-35$ km(e.g., Nadin and Saleeby, 2008). Structural and petrologic relations in the SCB and southernmost SNB indicate that the base of the batholith and underlying LC-SCML was sheared off at 30-35 km depth and replaced with trench materials (Grove et al., 2003; Saleeby, 2003; Chapman, 2017).

What was the fate of the sub-SCB LC-SCML? Do remnants of the displaced material exist, and if so, what is the relationship between LC-SCML remnants and underplated schist? Seismic data and receiver function analysis provide some answers to these questions, linking surface exposures of schist directly to a regional flat fabric with NE-SW seismic anisotropy beneath thin $(\sim 30 \mathrm{~km})$ Mojave crust (Cheadle et al., 1986; Porter et al., 2011). Additional constraints from geochemical data reveal an $\sim \mathrm{N}-\mathrm{S}$-trending boundary at $\sim 116^{\circ} \mathrm{W}$, west of which lacks a lithospheric isotopic fingerprint and suggests the presence of underplated schists (Miller et al., 1996). Collectively, these studies reveal a major compositional boundary within the mid- to deep crust of the central Mojave demarcating a western schist-bearing domain, and an eastern domain lacking significant schist and containing remnants of ancient LC-SCML (Fig. 1).

\section{Laramide Imprints in Xenoliths}

Xenolith suites of the SW Cordillera record development of the LC-SCML prior to, during, and following the Laramide event. Proterozoic upper mantle and lower crustal xenoliths in the Colorado Plateau and vicinity, in conjunction with $\mathrm{Nd}$ isotopic data on mafic volcanic rocks of the region, record local preservation of LC-SCML beneath the region through Laramide time (Livaccari and Perry, 1993).

Xenolith suites from the eastern and central Mojave region also provide evidence for underlying remnants of ancient LC-SCML. First, spinel peridotites from the PlioceneQuaternary Cima cones yield Re-Os model ages of 1.8-3.4 Ga (Fig. 1; Lee et al., 2001), overlapping ca. $2.0 \mathrm{Ga} \mathrm{Sm}-\mathrm{Nd}$ model ages on nearby Precambrian basement rocks (Bennett and DePaolo, 1987). Second, a subordinate group of peridotite xenoliths from the Quaternary Dish Hill cone yield $\varepsilon \mathrm{Nd}=-6.4$ to -13.0 (Fig. 1; Luffi et al., 2009). These data indicate that ancient LC-SCML was not entirely sheared off from beneath the eastern to central Mojave region by Laramide flat-slab subduction.

Remnants of pre- to syn-Laramide mantle lithosphere that constituted the mantle wedge for the SNB are present in late Miocene xenolith suites from the central SNB (e.g., Ducea and Saleeby, 1998; Ducea, 2001; Chin et al., 2012). Pressuretemperature-time constraints indicate that this fossilized mantle wedge extended to $\sim 125 \mathrm{~km}$ depth and cooled rapidly following the Late Cretaceous (Laramide) termination of magmatism (e.g., Ducea and Saleeby, 1998; Saleeby et al., 2003; Chin et al., 2012). Peridotites and garnet websterite dominate the base of the section and grade upward into an $\sim 45-\mathrm{km}$-thick zone of garnet clinopyroxenite followed by garnet granulite at $\sim 40 \mathrm{~km}$ paleodepth. Traceelement data and $\mathrm{Sm}-\mathrm{Nd}$ isochron ages indicate that the garnet clinopyroxenites are partial-melt residues, or deep level cumulates, linked to the overlying SNB (Ducea and Saleeby, 1998; Ducea, 2001). These garnet clinopyroxenites are com- 
monly referred to as eclogites, but contrast with classic eclogites by having more $\mathrm{Ca}$ and $\mathrm{Mg}$-rich clinopyroxene, more $\mathrm{Fe}$ - and Ca-rich garnet, and commonly contain accessory hornblende. These arc root cumulates are commonly referred to as "arclogites" (Anderson, 2005).

The preservation of $>100 \mathrm{~km}$ of central SNB lower lithosphere (arc root lower crust and upper mantle) contrasts sharply with the virtual absence of these materials beneath the SCB (Fig. 1). Geochemical proxies for crustal thickness (e.g., Sr/Y and $\mathrm{La} / \mathrm{Yb}$ ) strongly suggest that a deep sub-SCB root indeed existed prior to shallow-angle subduction, forming in the Late Jurassic and thickening significantly during the Late Cretaceous magmatic flareup (Howard et al., 2016). We now focus on the fate of missing SCB lower lithosphere and the regional extent of Farallon plate mantle lithosphere underplating beneath the "unrooted" SCB.

\section{SCB LOWER LITHOSPHERE DISPLACEMENT AND RECONSTRUCTION}

It is important to reiterate here that despite LC-SCML removal from beneath the SCB, and subsequent tectonic underplating of schist, the lithosphere-asthenosphere boundary in the Mojave region currently lies deeper than $\sim 60 \mathrm{~km}$ (e.g., Luffi et al., 2009). This profound relationship indicates that latest Cretaceous-Cenozoic reconstruction of the mantle lithosphere beneath the schists must have taken place.

Relationships resolved in Dish Hill and Crystal Knob xenolith suites (Fig. 1) indicate that the underlying mantle lithosphere was reconstructed by tectonic underplating of Farallon plate sub-oceanic mantle between 80 and $30 \mathrm{Ma}$ (Luffi et al., 2009; Liu et al., 2010; Quinn et al., 2018). Considering that eclogitic fragments of the Farallon Plate (Usui et al., 2003) plus significant amounts of ancient LC-SCML both underlie the Laramide interior, the lower lithosphere beneath a significant part of the Laramide corridor must be a composite of these assemblages. As shown on Figure 1, the underplated schists plus underlying mantle lithosphere constitute a lithosphere-scale accretionary complex lying beneath a carapace of SCB granitoids that was stripped of most of its underlying mantle wedge.
As to the fate of the displaced SCB LC-SCML, we suggest that several latest Oligocene lower lithosphere xenolith locations from the Colorado Plateau transition zone contain remnants of the missing lithosphere. This assertion predicts that native sub-arc materials and displaced equivalents should contain similar arrays of rock types. This is indeed the case, as ca. $25 \mathrm{Ma}$ latite at Camp Creek and Chino Valley localities each contain abundant nodules of, in order of decreasing abundance, garnet-pyroxene rocks, garnet granulite, peridotite, and quartzofeldspathic gneiss (Schulze and Helmstaedt, 1979; Arculus and Smith, 1979; Smith et al., 1994; Esperança et al., 1988, 1997; Erdman et al., 2016). As with the subSNB suite, garnet clinopyroxenite xenoliths from Chino Valley and Camp Creek are arclogitic in composition, and equilibrated between 600 and $900{ }^{\circ} \mathrm{C}$ and 12-28 kbar (45-100 km depth assuming a $2800 \mathrm{~kg} / \mathrm{m}^{3}$ overburden density; Smith et al., 1994; Esperança et al., 1988; Erdman et al., 2016). Furthermore, high field strength element compositions and major element systematics of Arizona xenoliths balance those expected from calc-alkaline magmatic differentiation (Tang et al., 2018, 2019). Finally, Mesozoic plutons of the Mojave Desert and arclogite recovered from Chino Valley and Camp Creek all share similar isotope systematics, with ${ }^{87} \mathrm{Sr} /{ }^{86} \mathrm{Sr}$ and $\varepsilon \mathrm{Nd}$ values ranging from 0.706 to 0.711 and -2 to -10 , respectively (Esperança et al., 1988; Smith et al., 1994; Miller et al., 1996). These relations point to a thick sub-SCB residue, rather than a lower plate, origin.

This assertion also predicts that materials once attached to the base of the SCB should share the early thermal history of the Mojave Desert. For example, the Mojave Desert is underlain chiefly by Middle Jurassic-Early Cretaceous (ca. 160-140 Ma) and Late Cretaceous (90-70 $\mathrm{Ma})$ arc plutonic assemblages with relatively small amounts of Mesozoic to Neoproterozoic metasedimentary rocks (Wells and Hoisch, 2008; Barth et al., 2008; Needy et al., 2009; Chapman et al., 2018). Hence, if xenoliths recovered from Chino Valley and Camp Creek localities are indeed consanguineous with the SCB, the xenoliths should yield chiefly Late Cretaceous and Late Jurassic ages. If instead the xenoliths are native to the Colorado Plateau transition zone, which exposes mainly 1.6-1.8 Ga YavapaiMazatzal basement overlain by Proterozoic to Mesozoic strata, much older ages are expected. It should be noted that ca. 70-55 Ma porphyry copper deposits and a ca. 190-160 Ma magmatic arc crop out a few tens of kilometers SW of the studied xenolith localities (GSA Data Repository Fig. DR1 ${ }^{1}$; e.g., Vikre et al., 2014; Tosdal and Wooden, 2015; Chapman et al., 2018). Hence, Latest Cretaceous-early Cenozoic and Early-Middle Jurassic xenolith zircon ages, readily distinguishable from Late Cretaceous and Late Jurassic ages expected from the Mojave Desert, may point to a SW Arizona origin.

\section{NEW RESULTS AND INTERPRETATIONS}

A small percentage ( $\sim 5 \%)$ of garnet-clinopyroxenite-amphibole xenoliths contains trace amounts of zircon. Zircon separated from host xenoliths were analyzed via laser ablation-multi-collector inductively coupled plasma-mass-spectrometry (LA-MC-ICPMS) at the Arizona LaserChron Center (see footnote 1).

Three xenolith groups were identified, based on lithologic relations and U-Pb zircon ages. Group 1 xenoliths contain a significant modal proportion of amphibole $(>10 \%)$, which overprints the primary arclogite assemblage, and are extensively injected and altered by host latite. Zircon grains extracted from these nodules yield a bimodal age distribution consisting chiefly of Late Jurassic (kernel density estimate peak at ca. $150 \mathrm{Ma}$ ) ages with a lower proportion $(\sim 25 \%)$ of Late Cretaceous-early Cenozoic (peak at ca. $70 \mathrm{Ma}$ ) grains (Fig. 2 ). The second group of xenoliths consists of relatively fresh arclogite (i.e., less injected with melt and containing less secondary amphibole). These samples contain zircon that yield a unimodal spread of concordant Cretaceous to early Cenozoic ages ranging from ca. 100-50 Ma with a peak centered at ca. $75 \mathrm{Ma}$ (Fig. 2). A final group of mid- to deep-crustal foliated granitic gneiss is less abundant than its deep-crust/ upper mantle arclogite counterparts and yields concordia ages of ca. 1.7 Ga (Fig. DR7 [see footnote 1]). These nodules are interpreted as Proterozoic assemblages native to central Arizona.

Our new results indicate that studied arclogitic xenoliths are coeval with the 


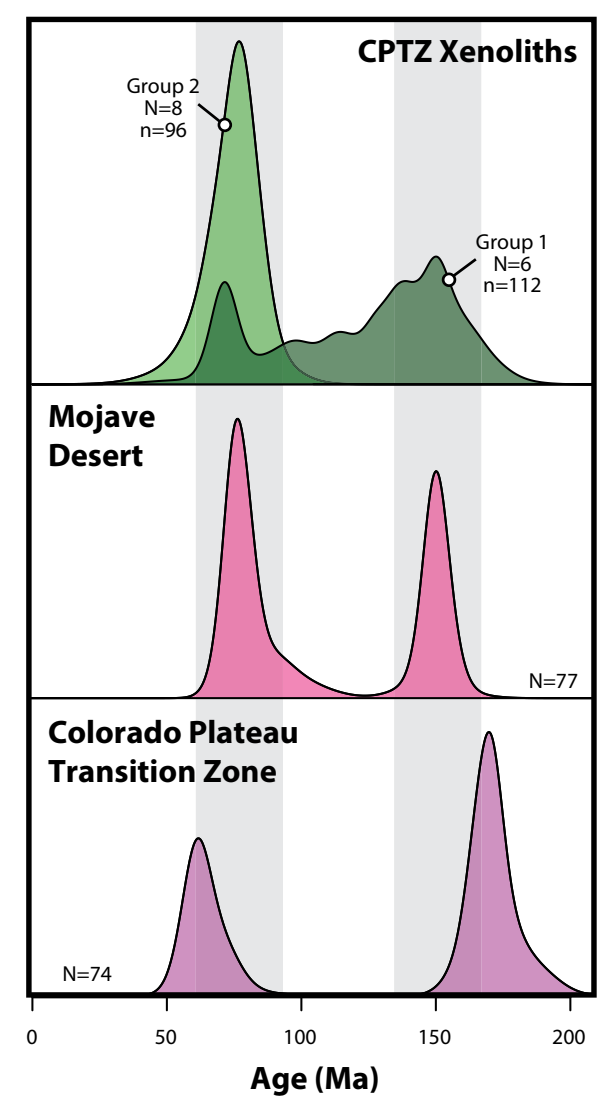

Figure 2. Non-normalized kernel density estimates with 10-m.y. bandwidth comparing U-Pb zircon ages from Colorado Plateau transition zone (CPTZ; Chino Valley and Camp Creek localities) xenoliths with pluton ages from the Mojave Desert (Barth et al., 2008; Wells and Hoisch, 2008; Needy et al., 2009; Chapman et al., 2018) and the CPTZ (Vikre et al., 2014; Tosdal and Wooden, 2015; Chapman et al., 2018). N-number of analyzed samples; $\mathbf{n}$-number of analyzed grains.

SCB and, with the exception of a small proportion ( $<10 \%$ of analyzed grains) of Latest Cretaceous-early Cenozoic grains, are older than Arizona porphyry copper deposits (Vikre et al., 2014; Chapman et al., 2018; Fig. 2). Furthermore, Late Jurassic zircon populations in group 1 xenoliths overlap Mojave Desert pluton emplacement ages and are younger than those expected from the Early-Middle Jurassic magmatic arc of SW Arizona (Fig. 2). These relations lead us to assert that arclogitic xenoliths are not native to central Arizona and instead represent LC-SCML fragments displaced eastward from beneath the SCB and reaffixed beneath the transition zone.

We propose the following model for the petrologic and tectonic evolution of Colorado Plateau transition zone arclogite (Figs. 3 and 4). In Late Jurassic time, group 1 (i.e., amphibole-rich arclogite) xenoliths began forming as a mafic keel to continental arc magmas
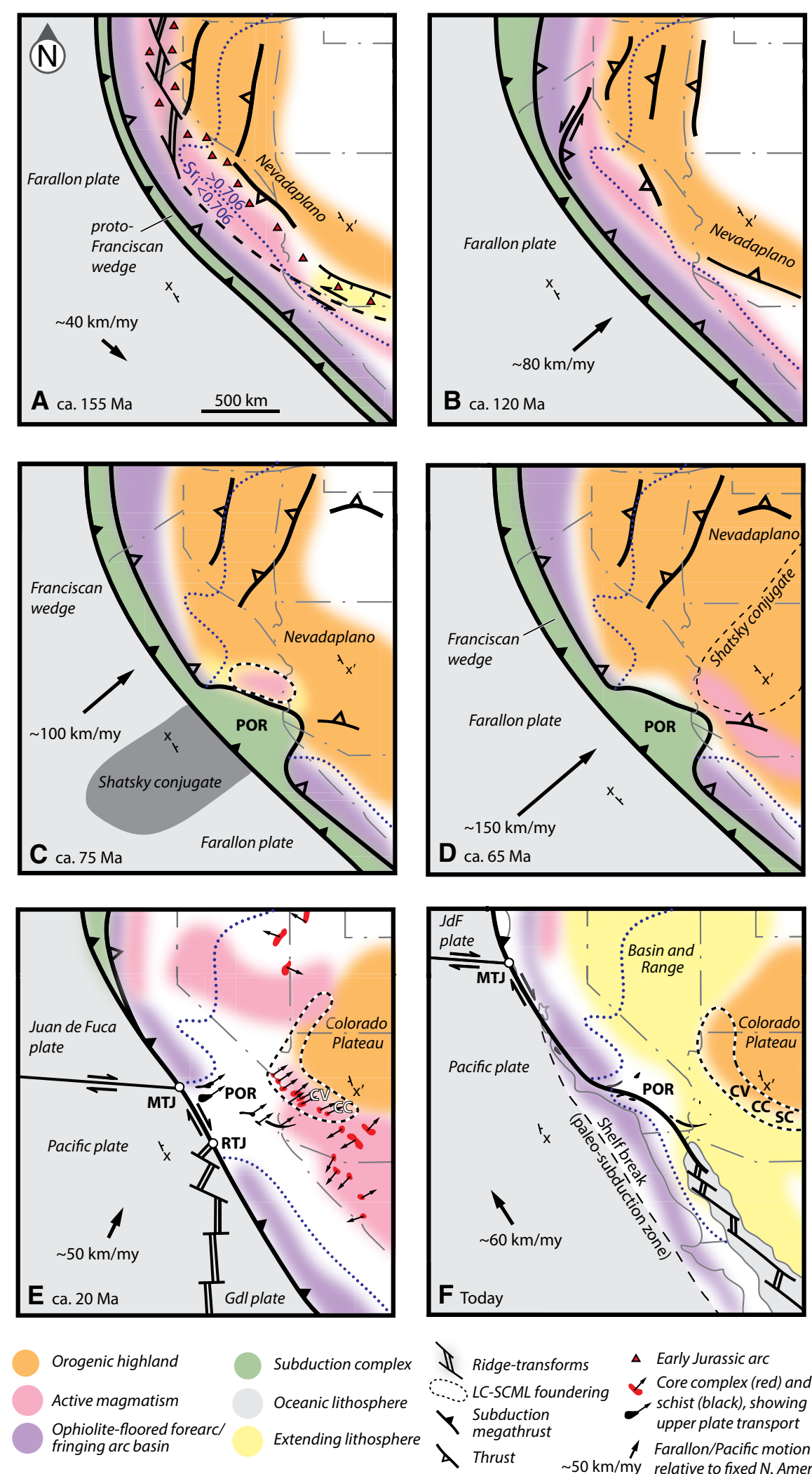

$\Delta$ Early Jurassic arc
Core complex (red) and
schist (black), showing
upper plate transport
Farallon/Pacific motion

Farallon/Pacific motion
relative to fixed N. America

Figure 3. SW U.S. plate tectonic reconstruction for (A) middle Jurassic, (B) Early Cretaceous, (C) Late Cretaceous, (D) Latest Cretaceous, (E) late Cenozoic, and (F) Recent time (modified after DeCelles, 2004; Saleeby and Dunne, 2015). Farallon/Pacific plate trajectories from Engebretsen et al. (1985). Surface outline of lowermost crust and upper subcontinental mantle lithosphere (LC-SCML) foundering from Levander et al. (2011) and Erdman et al. (2016). Core complex and schist kinematics from Dickinson (2009) and Chapman (2017), respectively. See text for details. CC-Camp Creek; CV-Chino Valley; MTJ-Mendocino triple junction; POR-Pelona-Orocopia-Rand schist; RTJ-Rivera triple junction; SC-San Carlos; Gdl-Guadalupe plate. 
emplaced into the central and eastern Mojave Desert crust (Barth et al., 2008; Needy et al., 2009; Chapman et al., 2018). Following an Early Cretaceous lull in arc activity, the subSCB root experienced a Late Cretaceous pulse of growth associated with increased magmatism in the SCB (Wells and Hoisch, 2008; Needy et al., 2009; Chapman et al., 2018), as recorded by ca. 80-70 Ma zircon ages in group 1 and 2 xenoliths. These Late Cretaceous additions to existing SCB root material and concomitant plutonism at higher levels of the crust likely resulted from delamination and foundering of LC-SCML, destabilized by slab shallowing-related lateral stresses, and ensuing upwelling of hot asthenosphere (Leventhal et al., 1995; Wells and Hoisch, 2008).

Shallow-angle subduction likely commenced at the plate margin in the ca. 90-75 Ma time interval, based on plate motion modeling and the timing of schist underplating (e.g., Grove et al., 2003; Liu et al., 2010; Chapman, 2017). The leading edge of the shallowly subducting segment likely reached the central Mojave Desert, then $\sim 500 \mathrm{~km}$ inboard from the margin, no later than $70 \mathrm{Ma}$, assuming an orthogonal converge rate of $100 \mathrm{~km} / \mathrm{m} . \mathrm{y}$. (Engebretson et al., 1985; Copeland et al., 2017). At this point, schist underplating continued while the slab shallowed quickly, shutting off magmatism in the SCB, dislodging its LC-SCML, and tectonically bulldozing these materials along the Moho and up to $\sim 500 \mathrm{~km}$ farther inboard to the Colorado Plateau transition zone (Axen et al., 2018). In the process, strong coupling along the subduction interface drove significant thickening of foreland crust and the formation of a vast orogenic plateau (DeCelles, 2004; Henry et al., 2012; Copeland et al., 2017; Chapman et al., 2018). (It should be noted that lower lithosphere is intact NE of the Colorado Plateau transition zone; hence, deformation along the Laramide corridor as far inboard as the Black Hills of South Dakota was likely due to horizontal end-loading, as suggested by Livaccari and Perry [1993].) Meanwhile, magmatism swept inboard, forming ca. 75-55 Ma granitic stocks and associated copper mineralization in the transition zone (Coney and Reynolds, 1977; Vikre et al., 2014). We suggest that the combination of magmatism and crustal thickening-related radiogenic heating precipitated Latest Cretaceous-early Cenozoic zircon growth in dislodged arclogite.
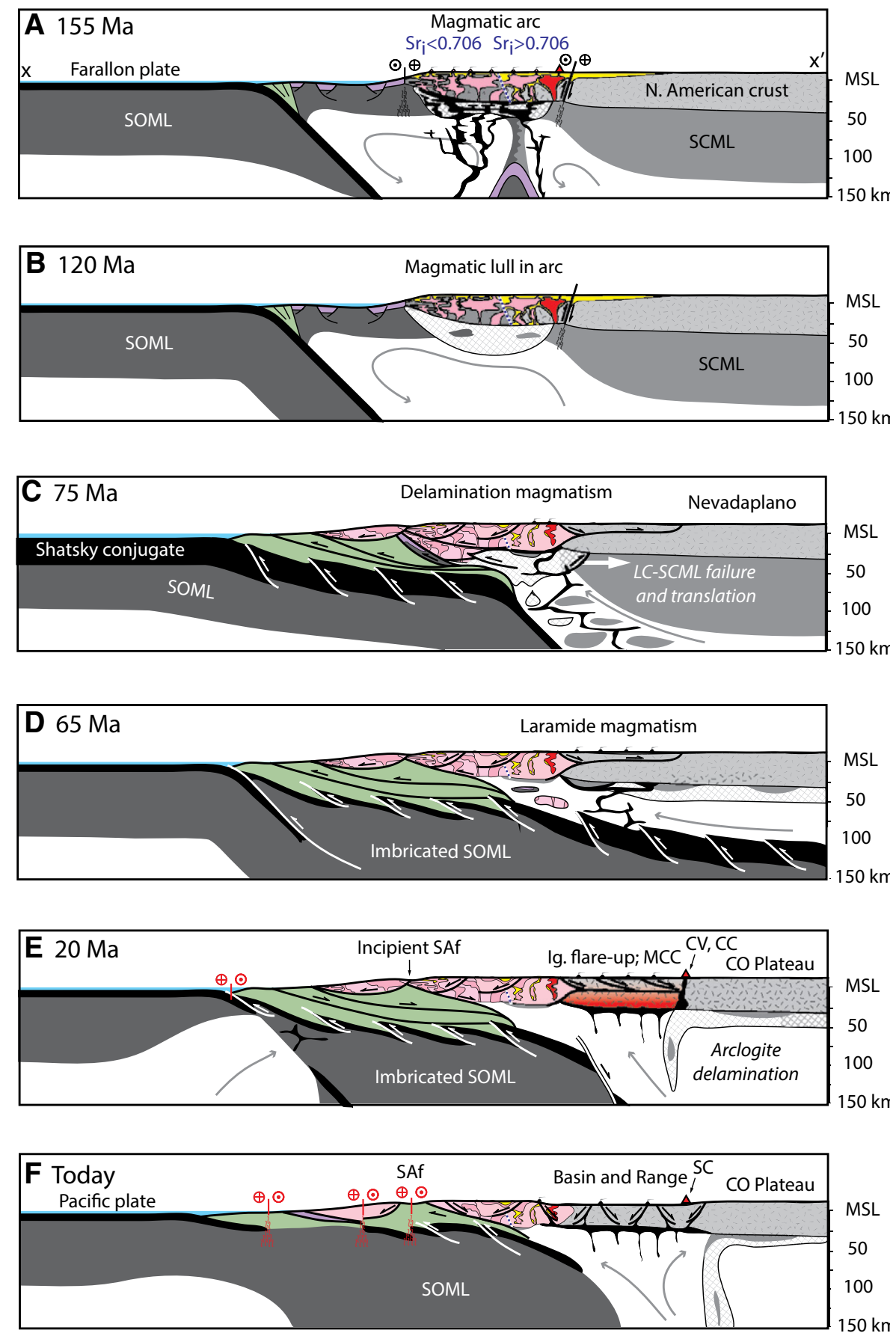

Figure 4. Cross sections corresponding to $x-x^{\prime}$ locations in Figure 3. Vertical equals horizontal scale. Colors correspond to those in Figure 3. See text for details. CC-Camp Creek; CO-Colorado; CVChino Valley; Ig.-ignimbrite; LC-lower crust; MCC-metamorphic core complexes; MSL-mean sea level; SAf-San Andreas fault; SC-San Carlos; SCML-sub-continental mantle lithosphere; SOMLsub-oceanic mantle lithosphere.

\section{A LASTING SCAR: CENOZOIC DELAMINATION AND EXTENSION IN THE SW UNITED STATES}

Xenolith garnet $\mathrm{Sm}-\mathrm{Nd}$ and titanite $\mathrm{U}-\mathrm{Pb}$ ages span the entire Paleogene, indicating that displaced arclogite remained hot $(>600$ ${ }^{\circ} \mathrm{C}$ ) for tens of millions of years following its dispersal (Dodson, 1973; Esperança et al., 1988; Erdman et al., 2016). This observation is readily explained by the welldocumented Eocene to Miocene westward sweep of magmatism (e.g., Coney and Reynolds, 1977; Copeland et al., 2017), including the ca. $25 \mathrm{Ma}$ arclogite xenolithhosting latite, that accompanied rollback and tearing of the Farallon slab. This time 
also marked a shift from convergent to extensional tectonism in the SW United States, including the initiation of the southern belt (i.e., California, Arizona, and Sonora) of Cordilleran metamorphic core complexes (Dickinson, 2009) and exhumation across the schist outcrop belt (e.g., Chapman, 2017).

The lack of arclogite and abundance of spinel peridotite xenoliths in ca. $15 \mathrm{Ma}$ and younger volcanic host rocks of the transition zone (e.g., the San Carlos locality; Nealey and Sheridan, 1989), in conjunction with a vertical high-seismic-velocity anomaly and the presence of a "double Moho" within the Colorado Plateau transition zone (Levander et al., 2011; Erdman et al., 2016), suggest that arclogite has been foundering into the mantle and being replaced by upwelling asthenosphere since early Miocene time. We speculate that post-Laramide rollback and tearing of the Farallon slab and associated influx of asthenosphere destabilized the foreign mafic keel of the Colorado Plateau, leading to its removal and heating of overlying material. Ensuing flow in the weakened lower crust, which remained feebly coupled to the upper crust, facilitated the localized surface extension that ultimately resulted in the southern belt of Cordilleran metamorphic core complexes.

\section{ACKNOWLEDGMENTS}

This effort benefitted from assistance by D. Abboud, B. Hunter, and J. Thole; discussions with S. Esperança and D. Smith; helpful reviews by G. Axen and C.-T. Lee; and editorial handling by P. Copeland. This work was supported by NSF grants EAR-1524768 (to ADC) and EAR-1725002 (to MND) and Romanian UEFISCDI projects PN-III-P4-ID-PCE-2016-0127 and PN-III-P4-IDPCCF-2016-0014 (to MND).

\section{REFERENCES CITED}

Anderson, D.L., 2005, Large igneous provinces, delamination, and fertile mantle: Elements, v. 1, p. 271-275, https://doi.org/10.2113/gselements .1.5.271.

Arculus, R.J., and Smith, D., 1979, Eclogite, pyroxenite, and amphibolite inclusions in the Sullivan Buttes latite, Chino Valley, Yavapai County, Arizona, in Boyd, F.R., and Meyer, H.O.A., eds., The Mantle Sample: Inclusions in Kimberlites and other Volcanics: Washington, D.C., American Geophysical Union Special Publications, v. 16, p. 309-317.

Axen, G.J., van Wijk, J.W., and Currie, C.A., 2018, Basal continental mantle lithosphere displaced by flat-slab subduction: Nature Geoscience, https://doi.org/10.1038/s41561-018-0263-9.

Barth, A.P., Wooden, J.L., Howard, K.A., and Richards, J.L., 2008, Late Jurassic plutonism in the southwest U.S. Cordillera, in Wright, J.E., and Shervais, J.W., eds., Ophiolites, Arcs and Batholiths: A Tribute to Cliff Hopson: Geological Society of America Special Paper 438, p. 379-396, https://doi.org/10.1130/2008.2438(13).

Bennett, V.C., and DePaolo, D.J., 1987, Proterozoic crustal history of the western United States as determined by neodymium isotopic mapping: Geological Society of America Bulletin, v. 99, p. 674-685, https://doi.org/10.1130/0016-7606 (1987)99<674:PCHOTW>2.0.CO;2.

Bird, P., 1988, Formation of the Rocky Mountains, western United States: A continuum computer model: Science, v. 239, p. 1501-1507, https://doi .org/10.1126/science.239.4847.1501.

Chapman, A.D., 2017, The Pelona-Orocopia-Rand and related schists of southern California: A review of the best-known archive of shallow subduction on the planet: International Geology Review, v. 59, no. 5-6, p. 664-701, https://doi.org /10.1080/00206814.2016.1230836.

Chapman, A.D., Saleeby, J., Wood, D.J., Piasecki, A., Kidder, S., Ducea, M., and Farley, K., 2012, Late Cretaceous gravitational collapse of the southern Sierra Nevada batholith, California: Geosphere, v. 8, p. 314-341, https://doi.org/ 10.1130/GES00740.1.

Chapman, J.B., Dafov, M.N., Gehrels, G., Ducea, M.N., Valley, J.W., and Ishida, A., 2018, Lithospheric architecture and tectonic evolution of the southwestern U.S. Cordillera: Constraints from zircon $\mathrm{Hf}$ and $\mathrm{O}$ isotopic data: Geologic Society of America Bulletin, v. 30, p. 2031-2046, https:// doi.org/10.1130/B31937.1.

Cheadle, M.J., Czuchra, B.L., Byrne, T., Ando, C.J., Oliver, J.E., Brown, L.D., Kaufman, S., Malin, P.E., and Phinney, R.A., 1986, The deep crustal structure of the Mojave Desert, California, from COCORP seismic reflection data: Tectonics, v. 5, p. 293-320, https://doi.org/ 10.1029/TC005i002p00293.

Chin, E., Lee, C.T., and Luffi, P., 2012, Deep lithospheric thickening and refertilization beneath continental arcs: Case study of the P, T and compositional evolution of peridotite xenoliths from the Sierra Nevada, California: Journal of Petrology, v. 53, p. 477-511, https://doi.org/10.1093/ petrology/egr069.

Coney, P.J., and Reynolds, S.J., 1977, Cordilleran Benioff zones: Nature, v. 270, p. 403-406, https://doi.org/10.1038/270403a0.

Copeland, P., Currie, C.A., Lawton, T.F., and Murphy, M.A., 2017, Location, location, location: The variable life span of the Laramide orogeny: Geology, v. 45, p. 223-226, https://doi.org/10.1130/ G38810.1.

DeCelles, P.G., 2004, Late Jurassic to Eocene evolution of the Cordilleran thrust belt and foreland basin system, western U.S.: American Journal of Science, v. 304, no. 2, p. 105-168, https://doi .org/10.2475/ajs.304.2.105.

Dickinson, W.R., 2009, Anatomy and global context of the North American Cordillera, in Kay, S.M., Ramos, V.A., and Dickinson, W.R., eds., Backbone of the Americas: Shallow Subduction, Plateau Uplift, and Ridge and Terrane Collision: Geological Society of America Memoir 204, p. 1-29, https://doi.org/10.1130/2009.1204(01).

Dodson, M.H., 1973, Closure temperature in cooling geochronological and petrological systems: Con- tributions to Mineralogy and Petrology, v. 40, p. 259-274, https://doi.org/10.1007/BF00373790.

Ducea, M.N., 2001, The California Arc: Thick granitic batholiths, eclogitic residues, lithosphericscale thrusting, and magmatic flare-ups: GSA Today, v. 11, p. 4-10, https://doi.org/10.1130/ 1052-5173(2001)011<0004:TCATGB >2.0.CO;2.

Ducea, M.N., and Chapman, A.D., 2018, Sub-magmatic arc underplating by trench and forearc materials in shallow subduction systems; a geologic perspective and implications: EarthScience Reviews, v. 185 , p. $763-779$, https://doi .org/10.1016/j.earscirev.2018.08.001.

Ducea, M.N., and Saleeby, J.B., 1998, The age and origin of a thick mafic-ultramafic keel from beneath the Sierra Nevada batholith: Contributions to Mineralogy and Petrology, v. 133, p. 169-185, https://doi.org/10.1007/s004100050445.

Engebretson, D.C., Cox, A., and Gordon, R.G., 1985, Relative Motions between Oceanic and Continental Plates in the Pacific Basin: Geological Society of America Special Paper 206, 59 p., https://doi.org/10.1130/SPE206-p1.

Erdman, M.E., Lee, C.-T.A., Levander, A., and Jiang, H., 2016, Role of arc magmatism and lower crustal foundering in controlling elevation history of the Nevadaplano and Colorado Plateau: A case study of pyroxenitic lower crust from central Arizona, USA: Earth and Planetary Science Letters, v. 439, p. 48-57, https://doi .org/10.1016/j.eps1.2016.01.032.

Esperança, S., Carlson, R.W., and Shirey, S.B., 1988, Lower crustal evolution under central Arizona: $\mathrm{Sr}$, $\mathrm{Nd}$, and $\mathrm{Pb}$ isotopic and geochemical evidence from mafic xenoliths of Camp Creek: Earth and Planetary Science Letters, v. 90, p. 26-40, https:// doi.org/10.1016/0012-821X(88)90108-2.

Esperança, S., Carlson, R.W., Shirey, S.B., and Smith, D., 1997, Dating crust-mantle separation: Re-Os isotopic study of mafic xenoliths from central Arizona: Geology, v. 25, p. 651-654, https://doi.org/ 10.1130/0091-7613(1997)025<0651:DCMSRO > 2.3.CO;2.

Grove, M., Jacobson, C.E., Barth, A.P., and Vucic, A., 2003, Temporal and spatial trends of Late Cretaceous-early Tertiary underplating Pelona and related schist beneath Southern California and southwestern Arizona: Geological Society of America Special Paper 374, p. 381-406, https://doi.org/10.1130/0-8137-2374-4.381.

Gutscher, M.A., Spakman, W., Bijwaard, H., and Engdahl, E.R., 2000, Geodynamics of flat subduction: Seismicity and tomographic constraints from the Andean margin: Tectonics, v. 19, p. 814-833, https://doi.org/10.1029/1999TC001152.

Henry, C.D., Hinz, N.H., Faulds, J.E., Colgan, J.P., John, D.A., Brooks, E.R., Cassel, E.J., Garside, L.J., Davis, D.A., and Castor, S.B., 2012, Eocene-Early Miocene paleotopography of the Sierra Nevada-Great Basin-Nevadaplano based on widespread ash-flow tuffs and paleovalleys: Geosphere, v. 8, p. 1-27, https://doi.org/10.1130/ GES00727.1.

Howard, K.A., Shaw, S.E., Allen, C., and Pearson, N.J., 2016, Mesozoic and Tertiary pluton sources in Mojave continental crust-Zircon U-Pb and Lu-Hf isotopic evidence: Geological Society of America Abstracts with Programs, v. 48, no. 4, https://gsa.confex.com/gsa/2016CD/webprogram/ Paper274508.html. 
Jacobson, C.E., Dawson, M.R., and Postlethwaite, C.E., 1988, Structure, metamorphism, and tectonic significance of the Pelona, Orocopia, and Rand schists, Southern California, in Ernst, W.G., ed., Metamorphism and Crustal Evolution of the Western United States, Rubey Volume: Englewood Cliffs, New Jersey, Prentice-Hall, p. 976-997.

Lee, C.T., Yin, Q.Z., Rudnick, R.L., and Jacobsen, S.B., 2001, Preservation of ancient and fertile lithospheric mantle beneath the southwestern United States: Nature, v. 411, p. 69-73, https:// doi.org/10.1038/35075048.

Levander, A., Schmandt, B., Miller, M.S., Liu, K., Karlstrom, K.E., Crow, R.S., Lee, C.-T.A., and Humphreys, E.D., 2011, Ongoing Colorado Plateau uplift by delamination-style convective lithospheric downwelling: Nature, v. 472, p. 461-465, https://doi.org/10.1038/nature10001.

Leventhal, J.A., Reid, M.R., Montana, A., and Holden, P., 1995, Mesozoic invasion of crust by MORB-source asthenosphere magmas, U.S. Cordilleran interior: Geology, v. 23, p. 399-402, https://doi.org/10.1130/0091-7613(1995)023 $<0399$ :MIOCBM > 2.3.CO;2.

Liu, L., Gurnis, M., Seton, M., Saleeby, J., Mueller, R.D., and Jackson, J.M., 2010, Predictions of oceanic plateau subduction beneath North America from plate reconstructions and inverse convection models: Nature Geoscience, https:// doi.org/10.1038/NGEO829.

Livaccari, R.F., and Perry, F.V., 1993, Isotopic evidence for preservation of Cordilleran lithospheric mantle during the Sevier-Laramide orogeny, western United States: Geology, v. 21, p. 719-722, https://doi.org/10.1130/0091-7613(1993)021 $<0719$ :IEFPOC $>2.3 . C O ; 2$.

Livaccari, R.F., Burke, K., and Şengor, A.M.C., 1981, Was the Laramide orogeny related to subduction of an oceanic plateau?: Nature, v. 289 , p. 276-278, https://doi.org/10.1038/289276a0.

Luffi, P., Saleeby, J., Lee, C.T.A., and Ducea, M., 2009, Lithospheric mantle duplex beneath the central Mojave Desert revealed by xenoliths from Dish Hill, California: Journal of Geophysical Research, v. 114, B3, https://doi.org/10.1029/ 2008JB005906

Miller, J.S., Glazner, A.F., and Crowe, D.E., 1996, Muscovite-garnet granites in the Mojave Desert: Relation to crustal structure of the Cretaceous arc: Geology, v. 24, p. 335-338, https:// doi.org/10.1130/0091-7613(1996)024<0335:MG GITM $>2.3 . \mathrm{CO} ; 2$.

Nadin, E.S., and Saleeby, J., 2008, Disruption of regional primary structure of the Sierra Nevada batholith by the Kern Canyon fault system, California, in Wright, J.E., and Shervais, J.W., eds. Ophiolites, Arcs and Batholiths: A Tribute to Cliff Hopson: Geological Society of America Special Paper 438, p. 429-454, https://doi.org/ $10.1130 / 2008.2438(15)$

Nealey, L.D., and Sheridan, M.F., 1989, PostLaramide volcanic rocks of Arizona and northern Sonora, Mexico, and their inclusions, in Jenny, J.P., and Reynolds, S.J., eds., Geologic Evolution of Arizona: Arizona Geological Society Digest, v. 17, p. 609-648.

Needy, S.K., Anderson, J.L., Wooden, J.L., Fleck, R.J., Barth, A.P., Paterson, S.R., Memeti, V., and Pignotta, G.S., 2009, Mesozoic magmatism in an upper- to middle-crustal section through the Cordilleran continental margin arc, eastern Transverse Ranges, California, in Miller, R.B., and Snoke, A.W., eds., Crustal Cross Sections from the Western North American Cordillera and Elsewhere: Geological Society of America Special Paper 456, p. 187-218, https://doi.org/ 10.1130/2009.2456(07).

Porter, R., Zandt, G., and McQuarrie, N., 2011, Pervasive lower crustal seismic anisotropy in southern California: Evidence for underplated schists: Lithosphere, v. 3, p. 201-220, https:// doi.org/10.1130/L126.1.

Quinn, D.P., Saleeby, J., Ducea, M., Luffi, P., and Asimow, P., 2018, Late-Cretaceous construction of the mantle lithosphere beneath the central California coast revealed by Crystal Knob xenoliths: Geochemistry Geophysics Geosystems, https://doi.org/10.1029/2017GC007260.

Saleeby, J.B., 2003, Segmentation of the Laramide Slab-Evidence from the southern Sierra Nevada region: Geological Society of America Bulletin, v. 115, p. 655-668, https://doi.org/10.1130/0016-7606 (2003)115<0655:SOTLSF $>2.0$. CO;2.

Saleeby, J., and Dunne, G., 2015, Temporal and tectonic relations of early Mesozoic arc magmatism, southern Sierra Nevada, California, in Anderson, T.H., Didenko, A.N., Johnson, C.L., Khanchuk, A.I., and MacDonald, J.H., Jr., eds., Late Jurassic Margin of Laurasia-A Record of Faulting Accommodating Plate Rotation: Geological Society of America Special Paper 513, p. 223-268, https://doi.org/10.1130/2015.2513(05).

Saleeby, J.B., Ducea, M.N., and Clemens-Knott, D., 2003, Production and loss of high-density batholithic root, southern Sierra Nevada, California: Tectonics, v. 22, https://doi.org/10.1029/ $2002 \mathrm{TC} 001374$.

Schulze, D.J., and Helmstaedt, H., 1979, Garnet pyroxenite and eclogite xenoliths from the Sullivan
Buttes, Chino Valley, Arizona, in Boyd, F.R., and Meyer, H.O.A., eds., The Mantle Sample: Inclusions in Kimberlites and other Volcanics: Washington, D.C., American Geophysical Union, p. 318-329, https://doi.org/10.1029/SP016p0318.

Smith, D., Arculus, R.J., Manchester, J.E., and Tyner, G.N., 1994, Garnet-pyroxene-amphibole xenoliths from Chino Valley, Arizona, and implications for continental lithosphere below the Moho: Journal of Geophysical Research, v. 99, B1, p. 683-696, https://doi.org/10.1029/93JB02994.

Tang, M., Erdman, M., Eldridge, G., Lee, C.-T.A., 2018, The redox "filter" beneath magmatic orogens and the formation of continental crust: ScienceAdvances, v. 4, no. 5, https://doi.org/ 10.1126/sciadv.aar4444.

Tang, M., Lee, C.-T.A., Chen, K., Erdman, M., Costin, G., and Jiang, H., 2019, Nb/Ta systematics in arc magma differentiation and the role of arclogites in continent formation: Nature Communications, v. 10 , p. 235 , https://doi.org/ 10.1038/s41467-018-08198-3.

Tosdal, R.M., and Wooden, J.L., 2015, Construction of the Jurassic magmatic arc, southeast California and southwest Arizona, in Anderson, T.H., Didenko, A.N., Johnson, C.L., Khanchuk, A.I., and MacDonald, J.H., Jr., eds., Late Jurassic Margin of Laurasia-A Record of Faulting Accommodating Plate Rotation: Geological Society of America Special Paper 513, p. 189-221, https://doi.org/10.1130/2015.2513(04).

Usui, T., Nakamura, E., Kobayashi, K., Maruyama, S., and Helmstaedt, H., 2003, Fate of the subducted Farallon plate inferred from eclogite xenoliths in the Colorado plateau: Geology, v. 31, p. 589-592, https://doi.org/10.1130/0091-7613 (2003)031<0589:FOTSFP $>2.0 . C O ; 2$.

Vikre, P.G., Graybeal, F.T., Fleck, R.J., Barton, M.D., and Seedorff, E., 2014, Succession of Laramide magmatic and magmatic-hydrothermal events in the Patagonia Mountains, Santa Cruz County, Arizona: Economic Geology and the Bulletin of the Society of Economic Geologists, v. 109, p. 1667-1704, https://doi.org/10.2113/ econgeo.109.6.1667.

Wells, M.L., and Hoisch, T.D., 2008, The role of mantle delamination in widespread Late Cretaceous extension and magmatism in the Cordilleran Orogen, western United States: Geological Society of America Bulletin, v. 120, p. 515-530, https://doi.org/10.1130/B26006.1.

MANUSCRIPT RECEIVED 26 Apr. 2019

Revised MANUSCRIPT RECEIVEd 12 Aug. 2019

Manuscript ACCePted 19 Aug. 2019 